\title{
Shared Reading for Valuing Diversity and Fostering Language Acquisition
}

\author{
Johanna Quiring and Franziska Vogt
}

\begin{abstract}
It is not unknown that children with a migration background often have fewer chances for a successful school career. Traditionally, a lack of skills in the common language is considered the cause of this inequality. Current discussions however offer multidimensional approaches and emphasise the fact that there are many more factors that account for this development. Nonetheless, good knowledge of the common language does support school success and thus remains an important factor. From an early childhood education perspective, the approach of incorporating language acquisition into it in everyday activities seems to be auspicious. Specific strategies to foster language skill acquisition in children that can be incorporated into everyday activities have been discerned. Among other methods, dialogic book reading is widely accepted as an evidence-based
\end{abstract}

Diese Publikation wurde durch den Open Access Publikationsfonds der Pädagogischen Hochschule St.Gallen (PHSG) gefördert.

The original version of this chapter was revised. The correction to this chapter is available at https://doi.org/10.1007/978-3-658-29809-8_16

\footnotetext{
J. Quiring $(\bowtie)$

Winterthur, Switzerland

e-mail: Johanna.Quiring@phsg.ch

F. Vogt

St. Gallen, Switzerland

e-mail: franziska.vogt@phsg.ch
}

(C) The Author(s) 2020, corrected publication 2020

E. Aslan (ed.), Migration, Religion and Early Childhood Education, Wiener

Beiträge zur Islamforschung, https://doi.org/10.1007/978-3-658-29809-8_1 
method to support children in enhancing their language skills. As important as the development of a conductive environment for the acquisition of language skills in institutions is the inclusion of the children's parents into this discussion. One possibility is to encourage parents to invest in the children's first language.

\section{Keywords}

Shared reading - Picture books - Early childhood education - Integration · Sequence analysis $\cdot$ Video analysis

\section{Introduction}

According to the Swiss Education Report 2018 (Wolter et al. 2018) and the UNICEF Report 2018 (UNICEF 2018), children with first languages other than the local language are subject to an educational disadvantage: the achievement gap in cantonal performance tests compared with other children increases throughout their primary education. At the age of 15 , nearly $30 \%$ of second-generation immigrants do not reach a basic level of reading proficiency in the local language-compared to approximately $15 \%$ of the children without an immigration background. In Germany, children with migration background are still underrepresented at grammar schools (Gymnasium) that prepare for university and consequently, they are overrepresented at the schools with lowest academic demands, which prepare for vocational studies (Hauptschulen) (Autorengruppe Bildungsberichterstattung 2018).

Traditionally, these pupils' deficits in German language skills are considered to be the cause of such inequality. Sufficient language proficiency is viewed as a prerequisite for education (Allemann-Ghionda 2006). However, there are other contributing factors too: for example, the structure of the educational system dividing pupils into different levels at an early age (Gomolla 2013), inadequate instructional quality and a lack of culture-sensitive diagnostics and assessments to just name a few (Allemann-Ghionda 2006). Nevertheless, German language proficiency does indeed support a successful school career (Dollmann and Kristen 2010). This will probably be the case as long as German remains the predominant language of schooling. It seems that in order to participate in society it is inevitable to acquire certain skills in the local language. Mecheril (2005) warns that the sole focus on language proficiency in the dominant language leads to a pedagogy of assimilation, and instead calls for a pedagogy acknowledging identities with multiple affiliations. Such a pedagogy would strive to recognise and value 
diversity as well as to encourage a sense of belonging to different cultures. This chapter aims at exploring ways to foster the acquisition of local language skills in a way that does not ask for assimilation but values diversity.

For this purpose, the first section of this chapter describes acculturation outcomes and their interrelations with personal well-being, mental health and social competences. Furthermore, the contribution of early childhood institutions as well as parents supporting the children in order to facilitate a positive acculturation outcome is discussed. The second section addresses ways of establishing a culture of recognition in early childhood institutions, which values children's individual characteristics such as their first languages. As a possible practical implementation, the third section introduces shared reading as a setting, which is already widely acknowledged for its positive effects on language acquisition. Shared reading is dialogic at its core and may therefore be a suitable setting to create a space to converse about sensitive topics like personal identities and backgrounds. Having laid out the theoretical and empirical contributions on valuing diversity and the potential of shared reading, the research question is examined based on a videotaped sequence. Sequence analysis was used to explore speech and multimodal aspects (Deppermann 2008; Mondada 2014). The explorative analysis of the video allows the identification of strategies and opportunities, which the educator may use in shared picture-book reading in order to value diversity. In the selected sequence, a multilingual picture book serves as a starting point to talk about languages in an institutional setting. Finally, hypotheses for further research as well as practical implications are discerned.

\section{Fostering Language Acquisition and an Adaptation Profile of Integration Rather Than Assimilation}

In this chapter, the acculturation process of young people with a migration background will be discussed in order to allocate the respective contributions of early childhood institutions and parents, aiming towards a healthy acculturation outcome for the children. Berry discerns four adaptation profiles for people living in a different culture than the one they originate from: assimilation, integration, separation and marginalization.

Assimilation is described as a tendency towards "relinquishing one's cultural identity and moving into the larger society" (Berry 1994, p. 240). In contrast, immigrants with an integration profile cultivate their heritage culture, while being in close contact with the dominant society at the same time. Immigrants 
with a separation profile are "primarily oriented towards their own ethnic group with limited involvement with the national society" (Berry et al. 2006, p. 232). Marginalization entails stress, loss of identity and rejection of the larger national society (Berry 1994).

Integration seems to be the least stressful adaptation strategy and is obtained through maintaining social relations within the heritage culture and cultivating traditions (separation) while also participating "in the national institutions" (assimilation) (Berry 1997, p. 28). In an international study including thirteen countries (e.g. Germany, France, USA, Australia and Israel) with 4,334 immigrant youth between the ages of 13 and 18, Berry et al. (2006) found that young people with an integration profile (36\% of the sample) scored highest in scales of personal well-being, mental health and "social competence in managing their daily life in the intercultural setting" (Berry et al. 2006, p. 306). Young people with an ethnic profile (tendency towards separation) scored second best on positive outcomes. They included $23 \%$ of the sample, whilst the national profile (tendency towards assimilation) included 19\%. 22\% displayed the diffuse profile with a tendency towards marginalisation. These findings imply that individuals should not be pushed towards assimilation by "denying ethnic cultural and language rights" (Berry et al. 2006, p. 328). On the contrary, "youth should be encouraged to retain both a sense of their own heritage cultural identity, while establishing close ties with the larger national society" (Berry et al. 2006, p. 306). For early childhood education, these findings imply that the well-being of children can be sustainably fostered by enabling children to find their place in their heritage culture as well as the larger national society.

According to Berry $(1997$, p. 28) also societies as a whole can contribute to the integration of immigrants by valuing "the benefits of pluralism" and taking a stance against discrimination and prejudice, while also supporting an integrational rather than an assimilatory adaptation approach. This could be achieved through "public education about the value of diversity" (Berry et al. 2006, p. 328). It is therefore not enough to focus on the immigrants and their adaptation processes: "A mutual accommodation is required for integration to be attained, involving the acceptance by both groups of the right of all groups to live as culturally different peoples" (Berry 1997, p. 10). According to Diehm, respect and recognition cannot be taught explicitly. Those values need to be lived and experienced rather than discussed in order to be passed on (Diehm 2010). For institutions of early childhood education to develop a culture of respect and recognition would include recognising and valuing the different languages that children speak (Edelmann 2018, p. 127). 
In their study, Berry et al. (2006) found that young people with an integration profile viewed themselves as highly proficient in the local language and averagely proficient in their ethnic language. This implies that it is wise to foster proficiency in the local language while being aware that the ethnic language should not be neglected. A Swiss research project showed, that the use of German at home in addition to the child's first language does not necessarily mean better German language skills in the long run (Troesch et al. 2017). Children's parents with migration background can thus be encouraged to speak their own language with their children. However, the attendance of an institution for early childhood education is a strong predictor (Grob et al. 2014). Parents can help their children to move towards an integration profile and to obtain good German language skillswhich supports educational success-by maintaining their heritage culture and language at home and sending their children to an institution of early childhood education at an early age, where they learn the local language embedded in everyday interactions with professionals and peers.

However, not only attendance of such an institutional setting is of importance but also the quality of the institution (Grob et al. 2014). Pianta et al. (2009, p. 50) emphasise interaction quality in early education and care: "for children enrolled in preschool, features of their experience in those settings are important-particularly, the ways in which adults interact with them to deliver developmentally stimulating opportunities". Research examining the quality of interaction yield unsatisfactory results for Germany (Fried 2010; Stuck et al. 2016) and Switzerland (Perren et al. 2016).

Encouragingly, intervention studies in German-speaking regions (Jungmann et al. 2013; Kucharz et al. 2014; Vogt et al. 2015) indicate, that professionals' competencies to provide cognitively stimulating instructional support for language learning can be increased through specific training. Girolametto et al. (2003) showed in a Canadian setting that professionals' gains of competencies lead to positive effects at child-level.

To sum up, on one hand, children need a decent language proficiency in the local language to be successful at school. On the other hand, they should remain involved with their ethnic culture to be able to adopt an acculturation profile of integration. Adolescents with this profile reported a high proficiency of the local language, an average proficiency of the ethnic language and a balanced use of both languages (Berry et al. 2006). The findings provide succours to the demand that knowledge of the ethnic language should be maintained. Parents need to be encouraged to offer their children a linguistically stimulating environment to develop and maintain proficiency in their ethnic language. Also, first languages 
should be recognised and valued in institutional settings of early childhood education (Edelmann 2018). In addition, early childhood education plays a crucial role in providing children with migration background with a learning context to get in touch with the larger society and learn the local language. It seems however, that interaction quality needs to be improved in such institutions in order to enhance the language acquisition and ensure the valuing of diversity. This can be obtained through professionalisation of educators.

The next section addresses the question how institutions can establish a culture of recognition in which children's individual characteristics such as affiliations with an ethnic group and different first languages are valued.

\section{Culture of Recognition}

According to Honneth (1996), recognition plays an important role in the development of a person's self-concept. Individuals need all forms of recognition (love, legal recognition and solidarity) to become self-confident and to develop both self-respect and self-esteem. The only way in which individuals are constituted as people is by learning to refer to themselves, from the perspective of an approving or encouraging other, as beings with certain positive traits and abilities. The scope of such traits - and hence the extent of one's positive relation-to-self-increases with each new form of recognition that individuals are able to apply to themselves as subjects. In this way, the prospect of basic self-confidence is inherent in the experience of love; the prospect of self-respect, in the experience of legal recognition; and finally the prospect of self-esteem, in the experience of solidarity (Honneth 1996, p. 538 f.).

As Mead (2013 [1934]) points out, the personality of an individual forms itself by belonging to a community; language is an important medium in this process. Children learn at home and in early childhood institutions what is common within these respective communities. They learn the meaning of gestures and words and develop their own image of themselves from the reactions of others (Mead 2013 [1934]). Unfortunately, children with a minority language as their first language often experience that their first language does not receive the same recognition as other languages that are associated with higher degrees of prestige (Herwartz-Emden et al. 2010). Generally, children with a migration background face additional challenges in the development of their personality, as they have to go through the process of acculturation in addition to common developmental tasks. According to Herwartz-Emden et al. (2010), the successful outcome of this 
process depends on whether the children receive appropriate support and recognition as well as experience success. Recognition can therefore be seen as a basic moral principle (Balzer and Ricken 2010). It is within the remit of pedagogy to develop (teaching) concepts that enable each individual to experience social recognition (Schäfer and Thompson 2010).

The concept of recognition, however, is not without its paradoxes. To recognise someone positions the person as being capable of acting, but the recognition itself simultaneously underlines the assumed inferior status of the one being recognised (Mecheril 2005). The dominant culture determines which identities are preferred and which ones are not. When granting recognition, there is the danger of "othering", as it is made visible, which characteristics are subject to recognition and which ones do not need to be recognised, as they are perceived as "normal". Recognition therefore reproduces power imbalances between the ones granting recognition and the ones being recognised. Of course, the power imbalance between professionals and children is constitutive for the pedagogic setting and can never be levelled out entirely (Bettmer 2008, p. 217). Consequently, it is even more important for educators to critically reflect their own actions (Mecheril 2005).

Diehm (2000) highlights another problem of the processes of granting recognition for ethnic differences in early childhood education: categories that work for politics do not per se work for young children. Young children do not perceive ethnic differences the same way as adults do. When adults apply those categories to children, there is a danger of reproducing a certain image that goes along with the identified difference. These political categories are unlikely to be differentiated enough to reflect the individual situation of each child. As a consequence, "doing difference" equals "doing inequality" (Mecheril and Plösser 2009, p. 201). Even if these categories are reflected in order to teach tolerance, stereotypes are passed on at the same time. In other words, recognition and misjudgement lie close together (Schäfer and Thompson 2010, p. 29).

As was pointed out, recognition is a vital concept for the development of children's personality. Children's diverse identities need to be valued. Paradoxically, to treat all children the same would lead to inequality (Diehm 2000; Mecheril and Plösser 2009). At the same time recognition is in danger of reproducing power imbalance and stereotypical categories. Mecheril (2005) and Diehm (2000) do not resolve those paradoxes, but demand that professionals are aware of them and reflect their actions. Schäfer and Thompson (2010) suggest, that educators should analyse the mechanisms of ascriptions critically and recognise the "other" as a source that helps to learn about how s/he is different from oneself.

Berry (1997) describes the most favoured adaptation style "integration" as a strategy in which aspects of assimilation and separation are merged. Children 
who are still in the process of acculturation and of personality development may not need recognition for the same characteristics. What one child would like to be recognised for may therefore change over time or from situation to situation. For example, a child might sometimes need recognition for local language skills and at other times for his or her multilingualism or ethnic language skills.

To sum up according to Mead (2013 [1934]) and Honneth (1996), belonging to a community and to experience recognition are vital for the development of children's personality and positive self-concept. As recognition and misjudgement lie close together it is suggested that the individuals in the position of receiving recognition have a say in determining what they want to be recognised for and that educators need to keep in mind that these aspects may change over time and depending on the situation.

In the following section, research results on the effects of shared reading on language acquisition are summarised and the potential of shared reading for opening a space to talk about different languages, cultures and identities is discussed.

\section{$4 \quad$ Shared Reading}

Shared reading is characterised by the active involvement of all participants in communicative interactions that evolve around a picture book. The participants are an adult person and one or more children (Ezell and Justice 2005). In 1988, Whitehurst et al. presented results of an experimental study showing that this form of picture-book reading actively involving children in the process of storytelling, can lead to a significant increase in the expressive and receptive vocabulary of two-year-olds. Whitehurst et al. (1988) called the approach 'dialogic reading,' it is however more widely known as 'shared reading'; with both terms having the same meaning. Shared reading has since been described as an effective form of language promotion, both when parents practice shared reading with their children (Whitehurst et al. 1988) as well as when the method is employed by educators (Lonigan and Whitehurst 1998; Whitehurst et al. 1994). Positive effects were also obtained with children with a low socio-economic status (Lonigan and Whitehurst 1998; Valdez-Menchaca and Whitehurst 1992; Whitehurst et al. 1994), with second language learners (Ennemoser et al. 2013; Hartung 2015; Roberts 2008) and with children at risk of developing language impairments (Ennemoser et al. 2015; Hargrave and Sénéchal 2000; Hartung 2015). The principle of shared picture-book reading was applied worldwide with good results, 
for example in Turkey (Simsek and Erdogan 2015), Chile (Valdez-Menchaca and Whitehurst 1992), Australia (Fitzgerald et al. 2016), Canada (Hargrave and Sénéchal 2000), Israel (Aram 2006) and Germany (Ennemoser et al. 2013).

During the dialogic interactions of shared reading, the adult person uses specific strategies to foster the child's language acquisition: language modelling (corrective feedback, expansions), asking specific questions (differentiating between closed, alternative and open questions) as well as extending vocabulary (Löffler and Vogt 2015). Shared reading is especially suitable to promote vocabulary because of the wide range of words depicted in the books that can be reproduced by the child itself during conversations (Wasik et al. 2016). A meta-analysis (Flack et al. 2018) confirmed a shared reading style as moderator for learning new words. In addition, other skills benefit from shared reading, for example phonological awareness (Aram 2006; Lonigan et al. 1999), language comprehension (Ennemoser et al. 2015; Hartung 2015) and letter knowledge (Aram 2006; Mol et al. 2009).

In institutions of early childhood education, the small group setting is often chosen over a one-to-one setting for reasons of capacity (Egert and Hopf 2018). The findings regarding the effectiveness of the small group setting are inconsistent and incomplete (Mol et al. 2009; Morrow and Smith 1990) and need further investigation. In any case, the simultaneous coordination of the participation of several children with heterogeneous language proficiencies and interests poses a challenge, but children also learn from their peers (Knapp et al. 2010; Wong Fillmore 1979). Thus the diversity of cultural and language backgrounds in one group supports discussing language(s) (Knapp et al. 2010).

As was described above, shared reading can be a powerful tool to support the acquisition of the local language. As shared reading requires teachers and children to engage in conversation, this setting provides a space to talk about different languages and cultural identities. Children might use this space to show aspects of their identity if the teacher restrains from making homogenising or pluralising comments (Brandstetter 2019).

This leads to the question of how educators should address and recognise cultural backgrounds and language diversity exactly, minimising the danger of misjudgements and of reproducing stereotypes. In the following section, a sequence of a shared reading session in a Swiss kindergarten will be analysed and suggestions for practical implementations of the ideas described above will be made. 


\section{Sequence Analysis of a Shared-Reading Situation}

Videos constitute a way of recording and preserving interactional events in image and sound (Tuma et al. 2013). For pedagogical questions, there are several approaches to the analysis of videos. A qualitative approach was adopted here. Dinkelaker and Herrle (2009) suggest qualitative video analysis as a form of analysis that keeps in close contact with the original video. The goal is to depict a variety of interaction processes and patterns, while maintaining their complexity. Through the lens of relevant theories, the interaction processes and patterns are analysed in order to discover the interrelations between the observable events and to extend or generate new theoretical concepts.

Sequence analysis was chosen as a methodological framework for the analysis as described by Deppermann (2008), focusing not only on speech but also on multimodal aspects (Mondada 2014). The transcription was conducted by the authors (using the programme Exmaralda) following cGAT-conventions (Schmidt et al. 2015). The analysis of "timing" was focused on (Deppermann 2008): when does the speaker change occur? Do speakers select themselves as next speakers or does the current speaker select the next speaker (Sacks et al. 1974)? How are verbal and nonverbal aspects of the conversation coordinated? Then the context was taken into account and alternative courses of action were discerned. Furthermore, aspects of language fostering as described by Vogt et al. (2015) were taken into account. The analysis was discussed in the research team for validation.

The sequence described in this chapter was selected because the conversation touches on questions of language and identity: a kindergarten teacher and three children (one of them with an Arabic-speaking-background) talk about Arabic letters in a bi-lingual picture book and about their personal relation to that language. The analysis of the sequence aims at depicting the conversational interactions and exploring how diversity is being valued. The sequence was video recorded by the authors within the framework of a comprehensive research project called SpriKiDS ${ }^{1}$ sponsored by interreg (Löffler et al. 2017) dealing with

\footnotetext{
${ }^{1}$ Project partners are the University of Education Weingarten (Germany), the St.Gallen University of Teacher Education (Switzerland), the Swiss University of Speech Therapy Rorschach (Switzerland), the University of Education Graubünden (Switzerland) and the University of Education Vorarlberg (Austria). The project team includes: Cordula Löffler (Lead), Franziska Vogt, Andrea Haid, Alexandra Zaugg, Eva Frick, Mirja Bohnert-Kraus, Oscar Eckhardt, Johanna Quiring, Laura von Albedyhll, Alexandra Waibel, Martina Zumtobel.
} 
language promotion integrated into everyday life in German-speaking regions around Lake Constance (Germany, Austria, Switzerland). For this project, kindergarten teachers were filmed on two mornings, the camera followed the teacher. Kindergarten teachers were asked to read from a picture book provided by the researchers to a small group of children at some point during the morning.

The sequence was videotaped in a Swiss kindergarten where Swiss-German is the predominant language. At the beginning of the lesson, the kindergarten teacher assigned a certain task (crafts and games) to each child by putting their nametag next to it. Three children, Ali (m), Noah (m) and Mia (f) found their nametags next to a book. Noah let the teacher know, that he had the same book at home. While the teacher assisted the other children to get started with their tasks, Ali, Noah and Mia sat down around the book. Mia and Noah sat in small chairs, Ali sat on the ground. When the teacher joined the group, she sat on the floor as well, facing Ali. Mia and Noah sat to her left on the chairs. The teacher picked up the book called Mr. Rabbit and Mrs. Bear (Kempter and Weldin 2008) and asked Ali and Mia whether they also knew the book which they then denied. After a short introduction of the protagonists shown on the book's cover, Mia and Ali helped to turn the first pages. The following dialogue occurred right after turning to the first page and had a duration of $65 \mathrm{~s}$ (not including an interruption of $20 \mathrm{~s}$ after second 35 that is not taken into account in the transcript and the analysis). Noah and Mia grew up speaking Swiss-German. Ali grew up speaking Arabic. In this sequence he spoke a mixture of Swiss dialect and Standard-German. All three children were six years old and about to enter first grade. In this version of the book, the text is written in German as well as in Arabic. The original score-transcript is reproduced as follows in a concise version for improved legibility:

1 Fachperson (FP): Gseht diis Buech au gnau so us Noah? (Noah nickt) Hä, isch nüt andersch? (Noah schüttelt den Kopf)

Teacher (T): $\quad$ Does your book look exactly the same, Noah? (Noah nods) Is there any difference? (Noah shakes his head)

2 Noah: Nur das häts nöd (zeigt im Buch auf die arabischen Schriftzeichen)

Noah: Only this isn't there. (points at the Arabic letters in the book)

3 FP: $\quad$ Das da häts nöd. (zeigt auf die arabischen Schriftzeichen im Buch) Was chönnt ächt das sii?

T: $\quad$ This here isn't there. (points at the Arabic letters in the book) What could it be? (looks at Mia) 
4 Mia:

Mia:

5 FP:

$T$ :

6 Ali:

Ali:

7 FP:

$T$ :

8 Ali:

Ali:

9 FP:

$F P$ :

10 Ali:

Ali:

$11 \mathrm{FP}$ :

$T$ :

12 Ali:

Ali:

13 Mia:

Mia:

14

15 FP:

$T$ :

16 Mia:

Mia:

17 FP: (zuckt mit den Schultern) Uf e anderi Sprach.

(shrugs) In a different language.

Uf e anderi Sprach ja genau. (nickt) Chönd ihr das läse? (FP schaut zu Mia und Noah, welche den Kopf schütteln, FP schüttelt ebenfalls den Kopf) Ich ä nid.

In a different language, yes, exactly. (nods) Can you read it? (the teacher looks at Mia and Noah who shake their heads, the teacher shakes her head as well) Me neither.

(überlappend) Aber mein ... Aber mein Bapi scho. (Augenkontakt mit FP)

(overlapping) But my ... But my Daddy can. (eye contact with T)

Gäll din Bapi scho und dis Mami ä? (Ali senkt den Blick)

Your daddy can and your mummy too? (Ali lowers his gaze) (nach einer Pause von $0.59 \mathrm{~s}$ ) Nein.

(after a pause of $0.59 \mathrm{~s}$ ) No.

Ned?

No?

(überlappend) Doch doch doch (fährt mit dem Finger auf dem Teppich herum, der Blick ist gesenkt)

(overlapping) Yes, yes she can. (moves with his fingers along the carpet, his gaze is still lowered)

Doch doch doch. Weisch dänn du was für e Sprach das isch?

Yes, yes she can. Do you know what language it is?

Hmmm. (kurzer Blickkontakt mit FP)

Hmmm. (short eye-contact with T)

Kroatisch?

Croatian?

A girl approaches the teacher and asks for help. The teacher helps her. After $20 \mathrm{sec}$ the girl goes away and the teacher resumes the dialogic book reading.

Was chönnts ächt für e Sprach sii? (schaut ins Buch und zeigt auf die arabischen Schriftzeichen im Buch)

What language could it be? (looks at the book and points at the Arabic letters in the book)

Kroatisch?

Croatian?

Kroatisch. 
$T:$

18 Ali:

Ali:

19 FP:

\section{Croatian.}

Oder Arabisch. (Blickkontakt mit der FP)

Or Arabic. (eye-contact with the teacher)

Ich gläbs ä, ich gläb s isch Arabisch. (FP nickt, Ali beginnt die Däumchen zu drehen)

$T$ :

I do think so too. I think it's Arabic. (T nods, Ali starts to twiddle his thumbs)

In this sequence, the joint focus of the teacher and the children was on the Arabic writing in the book. The teacher opened up a discussion by asking the open question "What could it be?" The teacher looked at Mia who then suggested that it might be a different language. The teacher answered in the affirmative and asked the rather rhetorical question if the children could read it. Most children are not yet able to read in kindergarten. With this question the teacher managed to create a personal link to the introduced topic. Ali selected himself as next speaker by saying that his father was able to read it. This passage can serve as an example how well-chosen questions posed by the teacher can lead to dialogues that evolve over multiple turns and include all participants. Further possible strategies to foster language skills (Vogt et al. 2015) like introducing, illustrating and repeatedly using new words or to model the children's utterances (e.g. to give corrective feedback or the expand on what the child said) cannot be observed in this sequence.

At the beginning of the sequence, the teacher and the children followed the typical pattern found in pedagogic settings described by Mehan (1979): The teacher asks a question, a child suggests an answers, which is then evaluated by the teacher. The teacher selects the child/children that is/are expected to give an answer by calling a name or looking at the child/children. Ali who is not addressed directly speaks up after the teacher has admitted that she cannot read the Arabic letters in the book (line 5). The teacher had asked the research team for the book with Arabic letters because of Ali's Arabic background. If he would not speak up, would the teacher keep on pressing on this matter or just go on talking about different languages in general or start to read the German text? If she would insist on Ali to mention his Arabic language background this could be viewed as an external categorisation, similar to what Diehm (2000) observed in a German kindergarten where the teacher addressed children as not having originated from the city they lived in. If the teacher would just carry on discussing languages in general or reading the book, the Arabic letters would serve as an opportunity for Ali to let the others know more about his Arabic background, but 
it would remain his choice whether he would like to do so or not and this choice would be respected by the teacher. Here, Ali speaks up (overlapping the teacher's statement) and mentions that his father can read this (line 6).

The teacher immediately reacted to this statement by affirming what Ali had said, adding the closed question about Ali's mother. Was she able to read it too (line 7)? Ali answered with "no". The teacher then reframed this "no" into a question and Ali took it back indicating that she could (line 10). After the teacher's question about Ali's mother, there was a pause of half a second. Ali broke eye contact with the teacher and lowered his gaze. Overlapping the teacher's evaluation ("no?") he said "yes yes she can" hastily. In her reaction to Ali's statement, the teacher did not remain in the realm of what had been said. Instead, she asked him about his mother. It is not clear what caused him to deny the teacher's question and then to take his word back again. It is obvious though, that the teacher did go beyond the information Ali shared and seemed to push him into a defensive position, being asked a series of closed questions (lines 7 and 11). A different reaction by the teacher would probably have led to a different continuation. For example, after recognising the fact that Ali's father was able to read the letters in the book (that even the teacher cannot read), she could have encouraged Ali to continue talking. She could have said "Wow, your daddy can read this? Would you like to tell us more about it?" With this strategy, Ali could have taken over the lead in the conversation and decided, what he would like to talk about with the group or he could signal the teacher that this was all he was ready to share.

The conversation is interrupted by another child asking the teacher for help with a toy. As soon as that child has gone, the teacher asked again what language it could be (line 15). This time, the question is not only directed at Ali. The auxiliary verb "could" is rather more reminiscent of a guessing game than of the interrogatory question before "Do you know ...?" (line 11). The teacher looked at the book rather than at a specific child or a group of children. Mia repeated her guess, lifting her voice at the last syllable of "Croatian" to make it sound like a question. Ali added "or Arabic", letting his voice become deeper at the end of the word, making it sound more like a fact than a question. The "or" framed his answer as another possibility next to Mia's suggestion. Although he could be considered as an expert in this matter (he already recognised earlier that his father would be able to read the letters), he seemed not too keen to be viewed as such as he did not claim to know it for sure. It is possible that he rather wanted to fit in joining the "guessing game".

Interestingly, Ali did not answer the teacher's question about what the language is called when she directly addressed him (line 11), but when the teacher 
asked the group after the interruption again (line 15) he spoke up and mentioned the name of the language he grew up with. This may be an indication that he felt less pressure to answer a question when he is not addressed directly, but when the teacher addressed the whole group and he could take his time to answer as and when he feels ready to do so.

The following section will discuss these findings regarding pedagogical implications about how to handle conversations with young children, especially when addressing a topic of personal identity.

\section{Implications for Pedagogy}

The observations made in the particular situation underline the importance for the teacher to choose specific questions to provide cognitive activation and engage the children in sustained dialogues. By responding appreciatively to the children's contributions, the teacher maintained an extended dialogue with all children. A sustained dialogue is fundamental in providing children with opportunities to advance their language proficiency (Girolametto et al. 2000; Vogt et al. 2015).

The analysis also leads to a few suggestions how teachers can create and handle situations in such a way that children can talk about identities, languages and cultural differences in a self-directed way. These implications serve as hypotheses for further studies. First, when the teacher chooses a book that includes the opportunity to talk about a certain topic, it should remain the children's choice if they wanted to talk about their personal link to this topic. This can be realised by asking general questions addressing the whole group. If the children do not jump to the opportunity to talk about their specific knowledge or experience, the teacher may keep the discussion at a general level or proceed to a different topic. When not dealing with topics that are linked to the children's personal identities the teacher can also address children directly who would otherwise remain silent in order to provide opportunities for language acquisition and participation. The teacher might, for example, ask how the story might go on or how a protagonist feels etc. Second, the teacher should listen carefully to what a child shares about his or her identity or background as this information can serve as a foundation to know what the child would like to be recognised for at this moment in time. Also, the teacher's comments of recognition should remain in the realm of what the child was ready to share and not push the topic any further with closed or directive questions, especially if the child signals that s/he is not ready to be 
addressed as an expert on this matter (for example his/her first language). This way the teacher has the chance to incidentally recognise and value shared differences, keeping the danger of misjudgement at bay and giving an example for a culture of recognition (Diehm 2010).

The suggestions made here are based on the analysis of a single case and should not be generalised. Analyses of more cases are needed to create a collection of comparable phenomena to finally extract generic patterns that lead to reliable results (Deppermann 2017). The analysis of this one sequence leads to a hypothesis that provides a starting point for further analysis. It also displays the complexity of the pedagogical setting and the high demands on the professional competence of early childhood educators.

\section{Conclusion}

As was shown, Berry's (1994, 1997; Berry et al. 2006) findings support Mecheril's (2005) idea for a pedagogical approach that takes identities with multiple affiliations into account. An acculturation profile of integration includes aspects of both, the ethnic and the local culture, and leads to the best adaptation outcomes with regard to personal well-being, mental health and social competences. To support the development of personality, belonging to a community and experiencing recognition are vital (Honneth 1996; Mead 2013 [1934]). However, "recognising" can also lead to the reproduction of stereotypical categories and power imbalances (Diehm 2000; Mecheril 2005). Recognition and misjudgement lie close together (Schäfer and Thompson 2010). By means of analysing a conversation between a kindergarten teacher and three children during a shared-reading session, several hypotheses were developed as starting points to reflect on ways to practically handle this paradox. It is proposed that the potential of shared reading for fostering language skills (Flack et al. 2018; Mol et al. 2009) but also for conversing about languages and cultural backgrounds (and other diversities like gender, religion etc.) can be harvested. If the teacher respects the children's boundaries concerning what they are ready to share about themselves and if they recognise the personal characteristics they mention, children will have the opportunity to create a link between their cultural background and the surrounding culture, while experiencing diversity being valued and recognised. This could be a possible approach to foster the acquisition of local language skills in a way that does not ask for assimilation, but values diversity. 


\section{References}

Allemann-Ghionda, C. (2006). Klasse, Gender oder Ethnie? Zum Bildungserfolg von Schüler/innen mit Migrationshintergrund. Von der Defizitperspektive zur Ressourcenorientierung. Zeitschrift für Pädagogik, 52(3), 350-362.

Aram, D. (2006). Early literacy interventions: The relative roles of storybook reading, alphabetic activities, and their combination. Reading and Writing, 19, 489-515.

Autorengruppe Bildungsberichterstattung. (2018). Bildung in Deutschland 2018. Ein indikatorengestützter Bericht mit einer Analyse zu Wirkungen und Erträgen von Bildung. Bielefeld: wbv.

Balzer, N., \& Ricken, N. (2010). Anerkennung als pädagogisches Problem. Markierungen im erziehungswissenschaftlichen Diskurs. In A. Schäfer \& C. Thompson (Eds.), Anerkennung (pp. 35-87). Paderborn: Schöningh.

Berry, J. W. (1994). Acculturation and psychological adaptation: An overview. In A.-M. Bouvy, F. J. R. Van de Vijver, P. Boski, \& P. Schmitz (Eds.), Journeys into cross-cultural psychology. Selected papers from the Eleventh International Conference of the International Association for Cross-Cultural Psycholgy (pp. 129-141). Lisse: Swets \& Zeitlinger.

Berry, J. W. (1997). Immigration, acculturation, and adaptation. Applied Psychology, 46(1), 5-34.

Berry, J. W., Phinney, J. S., Sam, D. L., \& Vedder, P. (2006). Immigrant youth: Acculturation, identity, and adaptation. Applied Psychology, 55(3), 303-332.

Bettmer, F. (2008). Partizipation. In T. Coelen \& H.-U. Otto (Eds.), Grundbegriffe Ganztagsbildung (pp. 213-221). Wiesbaden: VS Springer.

Brandstetter, B. (2019). Zwischen Homogenisierung und Pluralisierung. Elementarpädagogik inmitten religiös und weltanschaulich ambivalenter Ansprüche. ElFo - Elementarpädagogische Forschungsbeiträge, 1(1), 24-30.

Deppermann, A. (2008). Gespräche analysieren. Eine Einführung (4th ed.). Wiesbaden: VS Springer.

Deppermann, A. (2017). Konversationsanalyse und diskursive Psychologie. In G. Mey \& K. Mruck (Eds.), Handbuch Qualitative Forschung in der Psychologie. Wiesbaden: Springer.

Diehm, I. (2000). Erziehung und Toleranz. Handlungstheoretische Implikationen Interkultureller Pädagogik. Zeitschrift für Pädagogik, 46(2), 251-274.

Diehm, I. (2010). Anerkennung ist nicht Toleranz. In A. Schäfer \& C. Thompson (Eds.), Anerkennung (pp. 119-139). Paderborn: Schöningh.

Dinkelaker, J., \& Herrle, M. (2009). Erziehungswissenschaftliche Videographie. Eine Einführung. Wiesbaden: Verlag für Sozialwissenschaften.

Dollmann, J., \& Kristen, C. (2010). Herkunftssprache als Ressource für den Schulerfolg? Das Beispiel türkischer Grundschulkinder. Zeitschrift für Pädagogik/Beiheft, 55, 123-146.

Edelmann, D. (2018). Chancengerechtigkeit und Integration durch frühe (Sprach-)Förderung? Theoretische Reflexionen und empirische Einblicke. Wiesbaden: Springer VS.

Egert, F., \& Hopf, M. (2018). Wirksame Sprachförderung für mehrsprachige Kinder in Kindertageseinrichtungen. Theorie und Praxis der Sozialpädagogik, 3, 30-34.

Ennemoser, M., Kuhl, J., \& Pepouna, S. (2013). Evaluation des Dialogischen Lesens zur Sprachförderung bei Kindern mit Migrationshintergrund. Zeitschrift für Pädagogische Psychologie, 27(4), 229-239. 
Ennemoser, M., Lehnigk, M., Hohmann, E., \& Pepouna, S. (2015). Wirksamkeit eines Coachings für pädagogische Fachkräfte zur Optimierung der Förderpotenziale des Dialogischen Lesens. In A. Redder, J. Naumann, \& R. Tracy (Eds.), Forschungsinitiative Sprachdiagnostik und Sprachförderung - Ergebnisse (pp. 137-153). Münster: Waxmann.

Ezell, H. K., \& Justice, L. M. (2005). Shared storybook reading. Building young children's language \& emergent literacy skills. Baltimore: Paul H. Brookes.

Fitzgerald, T., Robillard, L., \& O'Grady, A. (2016). Exploring the impact of a volunteer shared reading programme on preschool-aged children. Early Child Development and Care, 188(6), 1-11.

Flack, Z. M., Field, A. P., \& Horst, J. S. (2018). The effects of shared storybook reading on word learning: A meta-analysis. Developmental Psychology, 54(7), 1334-1346.

Fried, L. (2010). Wie steht es um die Sprachförderkompetenz von deutschen Kindergartenerzieherinnen? - Ausgewählte Ergebnisse einer empirischen Studie. In H.-J. Fischer, P. Gansen, \& K. Michalik (Eds.), Sachunterricht und frühe Bildung (pp. 205-218). Kempten: Klinkhardt.

Girolametto, L., Weitzman, E., \& Greenberg, J. (2000). Learning language and loving it/ Teacher interaction and language rating scale/developed by Luigi Girolametto, Elaine Weitzman and Janice Greenberg. Toronto: The Hanen Centre.

Girolametto, L., Wetzman, E., \& Greenberg, J. (2003). Training day care staff to facilitate children's language. American Journal of Speech-Language Pathology, 12, 299-311.

Gomolla, M. (2013). Fördern und Fordern allein genügt nicht! Mechanismen institutioneller Diskriminierung von Migrantenkindern und-jugendlichen im deutschen Schulsystem. In G. Auernheimer (Ed.), Schieflagen im Bildungssystem. Die Benachteiligung der Migrantenkinder (pp. 87-102). Wiesbaden: Springer VS.

Grob, A., Keller, K., \& Trösch, L. M. (2014). Zweit Sprache. Mit ausreichenden Deutschkenntnissen in den Kindergarten. https://www.edubs.ch/schullaufbahn/vorkindergarten/studien-und-evaluationen. Accessed 17. April 2019.

Hargrave, A., \& Sénéchal, M. (2000). A book reading intervention with preschool children who have limited vocabularies: The benefits of regular reading and dialogic reading. Early Childhood Research Quarterly, 15(1), 75-90.

Hartung, N. (2015). Evaluation des Dialogischen Lesens unter Berücksichtigung der Durchführungsqualität. http://geb.uni-giessen.de/geb/volltexte/2016/11929/pdf/HartungNils_2015_12_17.pdf. Accessed 17. April 2019.

Herwartz-Emden, L., Schurt, V., \& Waburg, W. (2010). Aufwachsen in heterogenen Sozialisationskontexten. Zur Bedeutung einer geschlechtergerechten interkulturellen Pädagogik (5th ed.). Wiesbaden: VS Springer.

Honneth, A. (1996). The struggle for recognition: The moral grammar of social conflicts. Cambridge: Polity. (Trans. J. Anderson).

Jungmann, T., Koch, K., \& Etzien, M. (2013). Effektivität alltagsintegrierter Sprachförderung bei ein- und zwei- bzw. mehrsprachig aufwachsenden Vorschulkindern. Frühe Bildung, 2(3), 110-121.

Kempter, C., \& Weldin, F. (2008). Herr Hase und Frau Bär. Zürich: NordSüd.

Knapp, W., Kucharz, D., \& Gasteiger-Klicpera, B. (2010). Sprache fördern im Kindergarten. Umsetzung wissenschaftlicher Erkenntnisse in die Praxis. Weinheim: Beltz.

Kucharz, D., Kammermeyer, G., Beckerle, C., Mackowiak, K., Koch, K., Jüttner, A.-K., et al. (2014). Wirksamkeit von Sprachförderung. In B. Kopp, S. Martschinke, M. Munser-Kiefer, M. Haider, E. M. Kirschhock, G. Ranger, \& G. Renner (Eds.), Individuelle Förderung und Lernen in der Gemeinschaft (pp. 51-66). Wiesbaden: Springer. 
Löffler, C., \& Vogt, F. (Eds.). (2015). Strategien der Sprachförderung im Kita-Alltag. München: Reinhardt.

Löffler, C., Vogt, F., Haid, A., Frick, E., Zaugg, A., Bohnert-Kraus, M., et al. (2017). Dialekt und Standard im Kindergarten. Babylonia, 2, 45-47.

Lonigan, C. J., Anthony, J. L., Bloomfield, B. G., Dyer, S. M., \& Samwel, C. S. (1999). Effects of two shared-reading interventions on emergent literacy skills of at-risk preschoolers. Journal of Early Intervention, 22(4), 306-322.

Lonigan, C. J., \& Whitehurst, G. J. (1998). Relative efficacy of parent and teacher involvement in a shared-reading intervention for preschool children from low-income backgrounds. Early Childhood Research Quarterly, 13(2), 263-290.

Mead, G. H. (2013). Mind, self \& society. Berlin: heptagon. (1934).

Mecheril, P. (2005). Pädagogik der Anerkennung. Eine programmatische Kritik. In F. Hamburger, T. Badawia, \& M. Hummrich (Eds.), Migration und Bildung. Über das Verhältnis von Anerkennung und Zumutung in der Einwanderungsgesellschaft (pp. 311-328). Wiesbaden: Springer.

Mecheril, P., \& Plösser, M. (2009). Differenz. In S. Andresen, R. Casale, T. Gabriel, R. Horlacher, S. Larcher Klee, \& J. Oelkers (Eds.), Handwörterbuch Erziehungswissenschaft (pp. 194-208). Weinheim: Beltz.

Mehan, H. (1979). Learning lessons. Social organization in the classroom. Cambridge: Harvard University Press.

Mol, S. E., Bus, A. G., \& de Jong, M. T. (2009). Interactive book reading in early education: A tool to stimulate print knowledge as well as oral language. Review of Educational Research, 79(2), 979-1007.

Mondada, L. (2014). The local constitution of multimodal resources for social interaction. Journal of Pragmatics, 65, 137-156.

Morrow, L. M., \& Smith, J. K. (1990). The effects of group size on interactive storybook reading. Reading Research Quarterly, 25(1), 213-231.

Perren, S., Frei, D., \& Herrmann, S. (2016). Pädagogische Qualität in früh kindlichen Bildungs- und Betreuungseinrichtungen in der Schweiz. Erste Erfahrungen und Befunde mit dem CLASS Toddler Beobachtungsverfahren. Frühe Bildung, 5(1), 3-12.

Pianta, R. C., Barnett, W. S., Burchinal, M., \& Thornburg, K. R. (2009). The effects of preschool education: What we know, how public policy is or is not aligned with the evidence base, and what we need to know. Psychological science in the public interest, $10(2), 49-88$.

Roberts, T. A. (2008). Home storybook reading in primary or second language with preschool children: Evidence of equal effectiveness for second-language vocabulary acquisition. Reading Research Quarterly, 43(2), 103-130.

Sacks, H., Schegloff, E. A., \& Jefferson, G. (1974). A simplest systematics for the organization of turn-taking for conversation. Language, 50(4), 696-735.

Schäfer, A., \& Thompson, C. (2010). Anerkennung. Paderborn: Schöningh.

Schmidt, T., Schütte, W., \& Winterscheid, J. (2015). cGAT - Konventionen für das computergestützte Transkribieren in Anlehnung an das Gesprächsanalytische Transkriptionssystem 2 (GAT2). https://ids-pub.bsz-bw.de/frontdoor/deliver/index/docId/4616/file/ Schmidt_Schuette_Winterscheid_cGAT_2015.pdf. Accessed 17. April 2019.

Simsek, Z., \& Erdogan, N. (2015). Effects of the dialogic and traditional reading techniques on children's language development. Procedia - Social and Behavioral Sciences, 197, 754-758. 
Stuck, A., Kammermeyer, G., \& Roux, S. (2016). The reliability and structure of the classroom assessment scoring system in german pre-schools. European Early Childhood Education Research Journal, 24(6), 873-894.

Troesch, L. M., Keller, K., Loher, S., \& Grob, A. (2017). Umgebungs- und Herkunftssprache: Der Einfluss des elterlichen Sprachengebrauchs auf den Zweitspracherwerb der Kinder. Zeitschrift für Pädagogische Psychologie, 31(2), 149-160.

Tuma, R., Schnettler, B., \& Knoblauch, H. (2013). Videographie. Eine Einführung in die interpretative Videoanalyse sozialer Situationen. Wiesbaden: Springer VS.

UNICEF. (2018). An unfair start: Inequality in children's education in rich countries. https://www.unicef.org/publications/files/UNICEF-An-unfair-start-inequality-childreneducation_En.pdf. Accessed 17. April 2019.

Valdez-Menchaca, M., \& Whitehurst, G. (1992). Accelerating language development through picture book reading: A systematic extension to mexican day care. Developmental Psychology, 28(6), 1106-1114.

Vogt, F., Löffler, C., Haid, A., Itel, N., Schönfelder, M., \& Zumwald, B. (2015). Professionalisierung für alltagsintegrierte Sprachförderung in Kindergarten, Kita und Spielgruppe: Videobasierte Analyse zur Veränderbarkeit von Handlungskompetenzen. Empirische Pädagogik, 29(3), 414-430.

Wasik, B. A., Hindman, A. H., \& Snell, E. K. (2016). Book reading and vocabulary development: A systematic review. Early Childhood Research Quarterly, 37, 39-57.

Whitehurst, G., Falco, F., Lonigan, C., Fischel, J., DeBaryshe, B., Valdez-Menchaca, M., et al. (1988). Accelerating language development through picture book reading. Developmental Psychology, 24(4), 552-559.

Whitehurst, G. J., Arnold, D. S., Epstein, J. N., Angell, A. L., Smith, M., \& Fischel, J. E. (1994). A picture book reading intervention in day care and home for children from low-income families. Developmental Psychology, 30(5), 679-689.

Wolter, S., Cattaneo, M., Denzler, S., Diem, A., Hof, S., Meier, R., et al. (2018). Swiss education report. Aarau: Swiss Coordination Centre for Research. in Education.

Wong Fillmore, L. (1979). Individual differences in second language acquisition. In C. J. Fillmore, D. Kempler, \& W. S.-Y. Wang (Eds.), Individual differences in language ability and language behavior (pp. 203-228). New York: Academic Press.

Open Access This chapter is licensed under the terms of the Creative Commons Attribution 4.0 International License (http://creativecommons.org/licenses/by/4.0/), which permits use, sharing, adaptation, distribution and reproduction in any medium or format, as long as you give appropriate credit to the original author(s) and the source, provide a link to the Creative Commons license and indicate if changes were made.

The images or other third party material in this chapter are included in the chapter's Creative Commons license, unless indicated otherwise in a credit line to the material. If material is not included in the chapter's Creative Commons license and your intended use is not permitted by statutory regulation or exceeds the permitted use, you will need to obtain permission directly from the copyright holder.

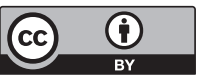

